\title{
Contribution of two-dimensional electrophoresis of proteins to maritime pine genetics
}

\author{
N Bahrman, C Plomion*, RJ Petit, A Kremer \\ Laboratoire de Génétique et Amélioration des arbres forestiers, \\ Inra, BP 45, F-33611 Gazinet cedex, France
}

(Received 24 November 1995; accepted 17 June 1996)

\begin{abstract}
Summary - Several investigations undertaken on maritime pine genetics using two-dimensional gel electrophoresis of megagametophyte, collected from germinated or non-germinated seed, needle, bud and pollen proteins, are reviewed in the present paper. Different extraction methods adapted to each tissue or organ allowed reproducible protein patterns to be obtained. Genetic studies deal with genetic diversity, differential genome expression and genome mapping. Using 16 protein loci, the allelic frequencies were scored and the mean genetic diversity and differentiation were estimated in 192 individuals from six different origins. Proteins whose expression is restricted to a single organ were shown to be more variable than unspecific proteins in a study comparing needle, bud and pollen proteins from 18 unrelated trees. The level of variability was slightly higher in the bud than that in the needle or the pollen. Moreover, larger proteins were shown to display more allelic diversity than proteins having a lower molecular weight. Ninety protein loci were found polymorphic in megagametophyte (haploid tissue) and were used to construct a linkage map containing 12 linkage groups. Twenty-seven and 17 protein loci showing Mendelian segregation in germinated seed megagametophyte and in needles of an $\mathrm{F}_{2}$ progeny, respectively, were introduced in another linkage map containing 436 random amplified polymorphic DNA (RAPD) markers. These studies outline the usefulness of the two-dimensional gel electrophoresis technique in genetic studies of conifers.
\end{abstract}

\section{diversity / linkage map / genome expression / 2D PAGE / Pinus pinaster}

Résumé - Apport de l'électrophorèse bidimensionnelle des protéines de mégagamétophytes à la génétique du pin maritime. Dans cet article de synthèse, nous présentons les recherches effectuées sur la génétique du pin maritime, en utilisant l'électrophorèse bidimensionnelle des protéines de mégagamétophytes prélevés sur des graines germées et non germées, d'aiguilles, de bourgeons et de pollens. Plusieurs méthodes d'extraction ont été utilisées afin d'obtenir des diagrammes protéiques reproductibles. Les études génétiques concernent la diversité génétique, l'expression différentielle du génome et la cartographie génétique. En utilisant 16 locus protéiques, les fréquences alléliques, la diver-

* Correspondence and reprints

Tel: (33) 05579790 76; fax: (33) 05579790 88; e-mail: plomion@pierroton.inra.fr 
sité génétique moyenne et la différentiation ont été calculées sur 192 individus de six origines différentes. Dans une étude concernant les aiguilles, bourgeons et pollens de 18 génotypes non apparentés, les bourgeons sont un peu plus variables que les deux autres organes ; par ailleurs les protéines spécifiques d'un organe sont plus variables que les protéines communes. Les protéines de haut poids moléculaire montrent plus de variation allélique que celles de petit poids moléculaire. Quatre-vingt dix marqueurs polymorphes du mégagamétophyte ont été cartographiés dans 12 groupes de liaisons. Dans une autre carte, 27 et 17 protéines polymorphes extraites respectivement de mégagamétophytes et d'aiguilles d'une famille $F_{2}$ ont été cartographiées avec 436 marqueurs RAPDs. Ces études montrent l'utilité de l'électrophorèse bidimensionnelle dans les recherches génétiques chez les conifères.

diversité / cartographie génétique / expression génomique / 2D PAGE / Pinus pinaster

\section{INTRODUCTION}

In many crop species, simply inherited morphological polymorphisms provided the first genetic markers. In contrast, in forest trees such markers have not usually been described and initial genetic analysis has been carried out with biochemical markers. In particular, in gymnosperm species, relative proportions of terpenes were used to characterize species, populations and provenances to analyze the structure of geographic variability (Schiller and Grunwald, 1987), to estimate genetic diversity and heterozygosity and to study genetic relationships among individuals (Esteban et al, 1976; Baradat et al, 1989). Using segregation data, a monogenic inheritance of terpenes was defended in many cases (Baradat et al, 1972, 1974; Marpeau et al, 1975, 1983; Yazdani et al, 1982). However, this simple mode of inheritance has been a matter of controversy. Irving and Adams (1973) showed that the biosynthesis of these compounds could be controlled by more than one gene.

Taking advantage of their codominant and multiallelic nature, isozyme markers have allowed more extensive exploration of genetic variation in forest tree populations. Many studies have estimated genetic variation, diversity and heterozygosity (Bergmann and Gregorius, 1979; Giannini et al, 1991) and differentiation (Szmidt, 1982; Müller-Starck, 1987; Müller-Starck et al, 1992 and the references therein; Petit et al,
1995). However, because of the limited number of enzymes for which assays are available (Conkle, 1981; Strauss and Conkle, 1986; Niebling et al, 1987), this technique could not be used for applications that need a broad genome coverage (ie, linkage analysis and QTL mapping).

The scope of genetic analysis for forest trees was enlarged by the use of restriction fragment length polymorphisms (RFLPs, Botstein et al, 1980). These codominant markers were used to investigate organelle DNA inheritance (Neale et al, 1986; Neale and Sederoff, 1989) and interspecific hybridization in natural populations (Wagner et al, 1987). A linkage map using RFLP markers has been recently presented for loblolly pine (Devey et al, 1994). Although RFLPs are almost unlimited in number, they require elaborate laboratory techniques, which makes them labor intensive, timeconsuming and costly (Kesseli et al, 1994). In addition, DNA content is so high in Pinaceae (Ohri and Khoshoo, 1986; Wakamiya et al, 1993) that single-copy Southern hybridization is particularly difficult in pines, requiring very lengthy exposures.

During the past 5 years, the development of a polymerase chain reaction (PCR)-based arbitrarily primed genetic assay called RAPD (random amplified polymorphic DNA, Williams et al, 1990), has greatly changed the prospects for application of molecular markers in forest trees. RAPD 
markers are unlimited and can provide powerful tools for population genetic studies (Bucci and Menozzi, 1993, 1995) and for genetic mapping (Plomion et al, 1995b). The dominance mode of inheritance of RAPD markers is not an issue for genetic mapping or population studies which use the haploid megagametophyte of gymnosperms (Tulsieram et al, 1992; Nelson et al, 1993; Binelli and Bucci, 1994; Plomion et al, 1995a), or when RAPD primers are screened for informative markers segregating 1:1 in diploid tissues (Carlson et al, 1991; Kubisiak et al, 1995). However, the conifer genome is characterized by a high proportion of repetitive DNA (Miksche and Hotta, 1973; Rake et al, 1980; Kriebel, 1985). Thus, RAPD markers tend to amplify from highly repetitive DNA (ie, mostly noncoding DNA) (Plomion et al, 1995b).

Two-dimensional electrophoresis of denatured proteins (2D PAGE) allows the analysis of several hundreds of gene products in a single gel (O'Farrell, 1975). In gymnosperm species proteins have been mainly used to study the genome expression under different stress (Sieffert and Queiroz, 1989; Ekramoddoullah et al, 1995) or expression over embryogenesis (Flinn et al, 1991; Domon et al, 1994) and modification of seed protein during germination
(Groome et al, 1991; Schneider and Gifford, 1994).

In this review, we summarize the studies that were undertaken in our laboratory with protein revealed by $2 \mathrm{D}$ PAGE in maritime pine (Pinus pinaster Ait) for population genetics, genome expression and genetic mapping. We explain why such a marker technique is valuable even though the assay and the interpretation of the gels require a tremendous amount of experience. Maritime pine is characterized by a fragmented range extending from southwestern France to northern Morocco. This species produces approximately $15 \%$ of the timber and pulp in France, with the production mainly located in the southwest.

\section{GENETIC STUDIES AND PLANT MATERIALS}

For the three kinds of genetic analyses that were undertaken in maritime pine (population genetics, genome expression and genome mapping), different types of populations were developed (table I). Both diploid (needles, buds, pollen mixtures) and haploid (megagametophyte) tissues were used. The haploid megagametophyte of gymnosperms derives from maternal meio-

Table I. Summary of genetic studies in maritime pine using two-dimensional electrophoresis of proteins.

\begin{tabular}{lllr}
\hline Type of study & Type of population & Reference & Study \# \\
\hline Population genetics & $\begin{array}{l}7 \text { provenances x 6 megagametophytes } \\
\text { 6 provenances x 32 megagametophytes }\end{array}$ & Bahrman et al, 1994 & Petit et al, 1995 \\
Genome expression & 18 individuals x 3 organs & Bahrman and Petit, 1995 & 3 \\
Linkage mapping & 1 individual x 56 megagametophytes & Bahrman and Damerval, 1989 & 4 \\
& 18 individuals x 12 megagametophytes & Gerber et al, 1993 & 5 \\
& $35 \mathrm{~F}_{2}$ individuals (haploid progeny) & Plomion et al, 1995a, b & 6 \\
& $68 \mathrm{~F}_{2}$ individuals (diploid progeny) & Plomion, 1995 & 7 \\
\hline
\end{tabular}


sis products and therefore represents the maternal gametic genotype.

\section{MATERIALS AND METHODS}

\section{Protein extraction, electrophoresis and staining}

The megagametophytes and embryos were collected from non-germinated seeds and were individually crushed in $6 \mu \mathrm{l} / \mathrm{mg}$ of $3 \mathrm{M}$ urea, $4 \%$ FSN-100 (ZONYL Fluorosurfactant, DuPont), $2 \%$ ampholytes (pharmalytes $\mathrm{pH} 3-10$ ) and $1 \%$ dithiothreitol in a $1.7 \mathrm{~mL}$ microcentrifuge tube (Anderson et al, 1985; Bahrman and Damerval, 1989). The mixture was briefly sonicated and extracted for $1 \mathrm{~h}$ at room temperature. After a brief centrifugation at $15000 \mathrm{~g}$ during $2 \mathrm{~min}$, the supernatants were removed and stocked at $-20{ }^{\circ} \mathrm{C}$ until isoelectrofocusing. The megagametophyte from a germinated seed was collected just before the germinant was ready to cast its seed coat. The seed coat still contained the residual megagametophyte inside. They were individually extracted in $6 \mu \mathrm{l} / \mathrm{mg}$ in the UKS $(9.5 \mathrm{M}$ urea, $5 \mathrm{mM} \mathrm{K}_{2} \mathrm{CO}_{3}, 1.25 \%$ SDS [sodium dodecyl sulfate], $0.5 \%$ dithiothreitol, $2 \%$ pharmalyte $\mathrm{pH} 3-10$ and $6 \%$ Triton X-100) buffer (Damerval et al, 1986) and the supernatants were stored at $-80{ }^{\circ} \mathrm{C}$ after centrifugation at $15000 \mathrm{~g}$ for $2 \mathrm{~min}$. Secondary needle and bud proteins were extracted according to Damerval et al (1986). Liquid nitrogen powdered tissue was homogenized with $10 \%$ TCA (trichloroacetic acid) and $0.07 \% 2$-mercaptoethanol in acetone. Proteins were precipitated for $1 \mathrm{~h}$ at $-20^{\circ} \mathrm{C}$. After centrifugation at $15000 \mathrm{~g}$ for $15 \mathrm{~min}$, the protein pellets were rinsed with acetone containing $0.07 \% 2$-mercaptoethanol for $1 \mathrm{~h}$ at $-20^{\circ} \mathrm{C}$. The supernatant was removed and protein pellet vacuum-dried and solubilized in $15 \mu \mathrm{l} / \mathrm{mg}$ of UKS buffer. The pollen proteins were extracted directly by UKS buffer, using $30 \mu \mathrm{l}$ of UKS per $1 \mathrm{mg}$ of pollen mixture and the supernatants were saved after centrifugation at $15000 \mathrm{~g}$ for $5 \mathrm{~min}$. The quantities of extract to be solubilized in UKS buffer was determined on the basis of protein pattern comparisons in these different tissues. Our goal was to obtain a similar amount of proteins for 2D gel comparison (about 60-70 $\mu \mathrm{g}$ of total protein per tissue).

The isoelectrofocusing (IEF) rod gels were $24 \mathrm{~cm}$ long and $1.5 \mathrm{~mm}$ in diameter. The mixture was $4 \%$ acrylamide, $9.2 \mathrm{M}$ urea, $2 \%$ Triton $\mathrm{X}$ 100 and $4 \%$ ampholytes (3/4 pharmalyte $\mathrm{pH} 5-8$, $1 / 4$ pharmalyte $\mathrm{pH}$ 5-6). The IEF was performed for $40000 \mathrm{Vh}$ with $50 \mathrm{mM} \mathrm{NaOH}$ and $50 \mathrm{mM}$ $\mathrm{H}_{3} \mathrm{PO}_{4}$ as electrode solutions. The SDS dimension was realized on slab gels $(200 \times 240 \times 1 \mathrm{~mm})$ bound to Gelbound PAG (marine colloids) in a Dalt tank. Uniform gel composition was $11 \%$ acrylamide, $0.5 \mathrm{M}$ Tris- $\mathrm{Cl}^{-} \mathrm{pH}$ of $8.8,0.15 \%$ SDS and $1 \%$ sucrose (Bahrman and Damerval, 1989). The running buffer was composed from $0.025 \mathrm{M}$ Tris, $0.192 \mathrm{M}$ glycine and $0.1 \%$ SDS. The gels were simultaneously run and silverstained according to Damerval et al (1987) in the apparatus described by Granier and de Vienne (1986).

\section{Scoring methods}

The comparisons of protein patterns were made visually by superimposition of the dried gels upon a light source. Coelectrophoresis 1:1 of different tissues of the same genotypes were performed to ascertain the differences in spot position. Variations in protein patterns of two-dimensional gels were classified in three groups:

i) Presence/absence variation, defined as the presence of a spot in one genotype and the absence of the same spot in another genotype. Such variation could correspond to quantitative variation where the non-visible polypeptide is below the level of detection by silver-staining. Another possibility is that one of the alleles is indeed 'silent', ie, never encoding any product (fig 1). In a haploid progeny we observed the $1: 1$ segregation ratio for presence and absence of a spot (Plomion et al, 1995b).

ii) Position variation concerned two polypeptides relatively close to each other on $2 \mathrm{D}$ pattern, usually having the same molecular weight but differing in the isoelectric point. These two polypeptides were considered as two products of a single structural gene with codominant inheritance (fig 2). In a $\mathrm{F}_{2}$ selfed progeny we observed the 1:2:1 segregation ratio expected for a codominant marker (Plomion, 1995).

iii) Staining intensity variation concerned a polypeptide showing different quantity in different genotypes. With visual scoring only two classes could be detected (fig 3 ). This case could be explained by a major gene responsible for the determinism of polypeptide amount. 

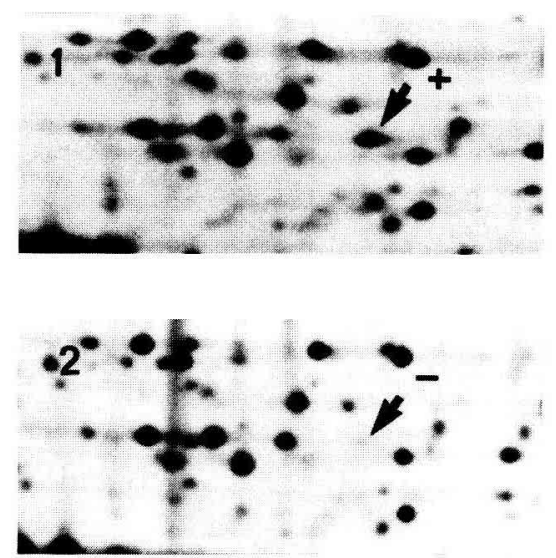

Fig 1. Cuttings from 2D gels. Arrows show a presence $\neq(+) /$ absence $(-)$ variation in the megagametophytes of two genotypes.
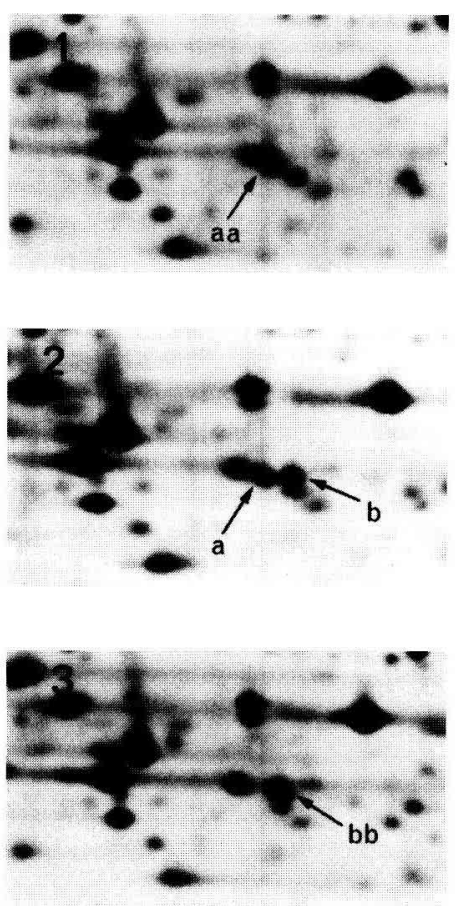

Fig 2. Cuttings from $2 \mathrm{D}$ gels showing a position variation in the needles of three genotypes: 1 and 3 , homozygous genotypes (aa and bb, respectively); 2 , heterozygous genotype (ab).
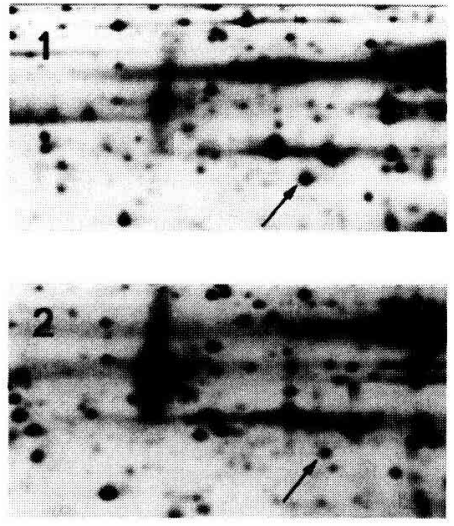

Fig 3. Cuttings from 2D gels. Arrows show staining intensity variation in the megagametophytes of two genotypes.

The genetic bases of these variations are largely discussed in Bahrman and Damerval (1989) and Bahrman and Petit (1995). Some examples of protein patterns are presented in figure 4 .

\section{Nature of the data and statistical analyses}

No particular treatment is required for analyzing the data gathered from the analysis of megagametophytes except that their haploid nature must be borne in mind. This particularity facilitates the genetic interpretation of the complex bidimensional gels since segregation analysis can be easily carried out.

For genetic mapping with haploid megagametophytes, linkage relationships among protein loci were determined under the backcross model (table I, studies \#4 and \#6), whereas human genetic techniques (Lander and Green, 1987) were used to construct the linkage map with megagametophytes collected from 18 individuals (study \#5). The localization of protein loci assayed in diploid tissue (study \#7) into a 'RAPD-megagametophyte' based map (study \#6) involved cosegregation analysis between RAPD and protein markers assayed on needles of the $\mathrm{F}_{2}$ seedlings. 

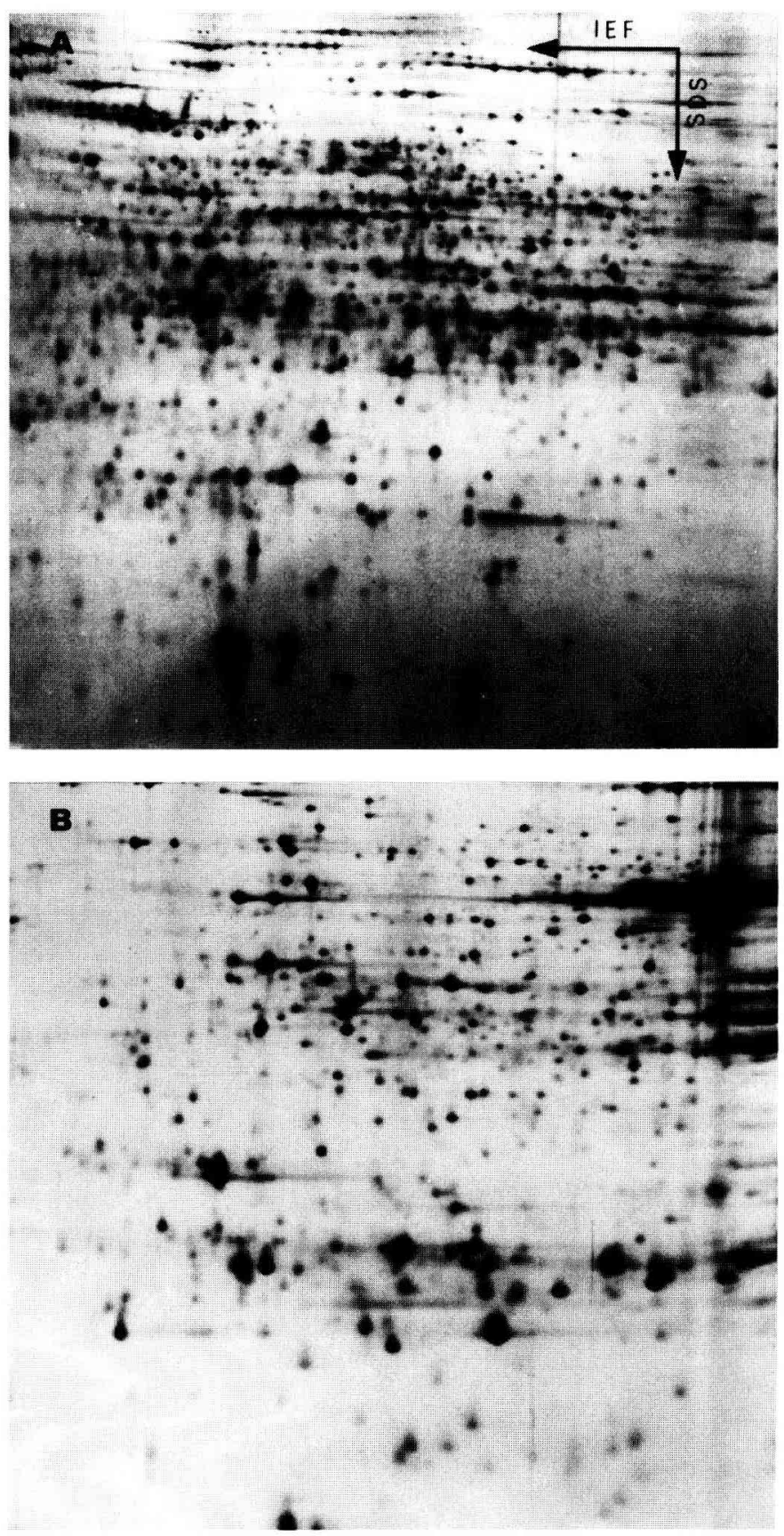

Fig 4. Two-dimensional electrophoresis gel of proteins extracted from A) pollens, B) needle and C) megagametophyte of maritime pine. IEF: isoelectrofocusing; SDS: sodium dodecyl sulfate. Images are available through the following internet address: http://www.pierroton.inra.fr/genetics/2D 


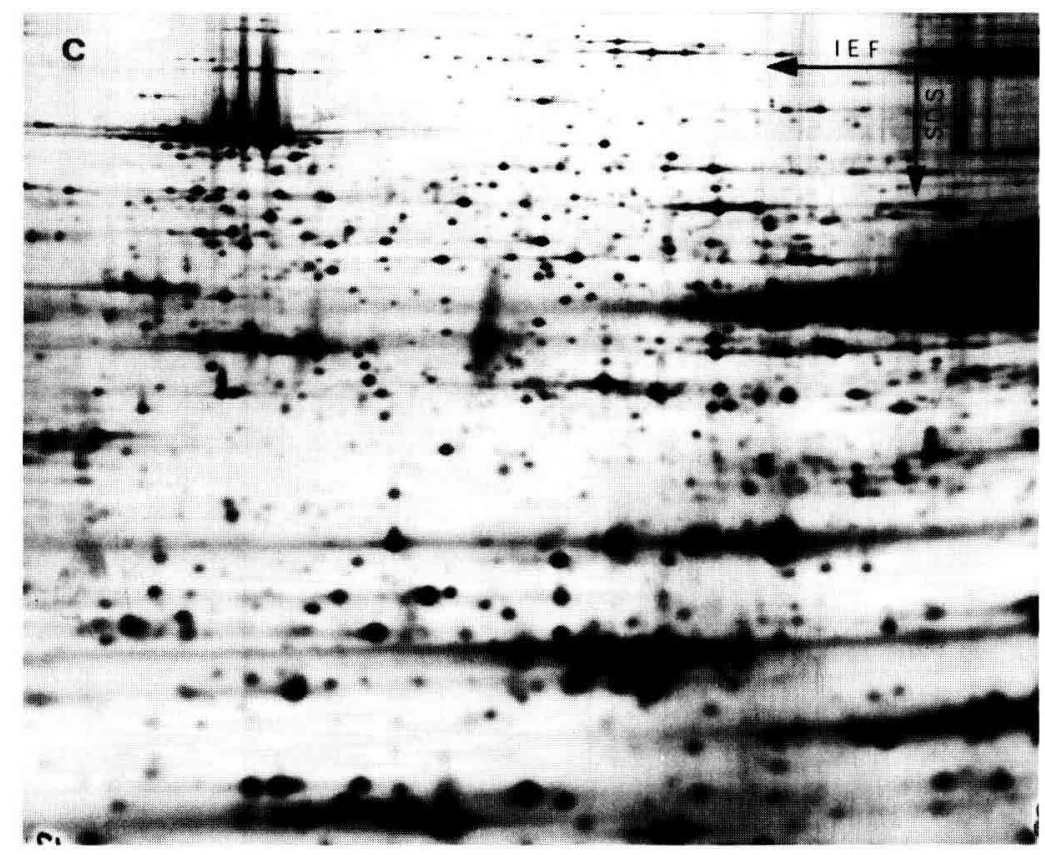

Fig 4. (continued)

\section{RESULTS AND DISCUSSION}

Each type of marker presents advantages and limitations and many factors can influence the choice of a marker system for a given purpose in conifer species. Molecular markers have been used for linkage map construction (see references in the Introduction), quantitative traits dissection experiments (Groover et al, 1994; Plomion, 1995) and genetic fingerprinting (Mosseler et al, 1992). Here, using the different results of already published studies we demonstrate the interest of protein markers for population genetics, differential gene expression studies and the mapping of the expressed genome.

\section{Genetic diversity}

Taking advantage of the possibility to distinguish between allelic forms of the pro- tein loci with single tree megagametophyte analysis, we compared the allelic frequencies of several protein loci in six different populations from the natural range of maritime pine (table I, study \#2). Sixteen protein loci were scored in the 32 megagametophytes of each origin. Mean diversity and differentiation were computed (Nei's genetic diversity and differentiation, Nei, 1987). The mean diversity was 0.45 and the differentiation was 0.17 , a relatively high value for conifers, probably reflecting the limited genetic exchanges among the populations of this species characterized by a fragmented range. The partitioning of total diversity was very similar when isozymes and terpenes were used to measure differentiation on the same set of populations. In another study (table I, study \#1), 42 megagametophytes belonging to seven different origins were analyzed. The comparison of the 42 protein patterns was made without attempting to 
interpret the genetical basis of the polymorphisms, ie, only presence/absence variation was considered. It was shown that more than $84 \%$ of the polypeptides were variable. The intra- and inter-origin distances were computed (Bahrman et al, 1994): the mean intra-origin distance was 0.268 , whereas the mean inter-origin distance was slightly higher $(0.308)$. Three groups were identified. The first included the individuals from Landes, Portugal, Spain and Corsica, the second the individuals from Italy and Sardinia and the third the individuals from Morocco.

\section{Genome expression}

Differential genome expression was demonstrated in another study using needle, bud and pollen protein patterns in 18 unrelated individuals from the Landes provenance (table I, study \#3). Among the 902 polypeptides found in the three organs, $245(27 \%)$ were variable among the genotypes, 117 of which were detected in a single organ. Altogether, only about $10 \%$ of the polypeptides found in an organ are specific to this organ. However, these polypeptides are three times as variable among the 18 genotypes as the other polypeptides!

Although the organ-specific polypeptides showed a higher level of variability for all three types of polymorphisms, mobility variants (position variation) were twice as frequent, presence/absence variants were three times as frequent, and quantitative variants were five times as frequent among organspecific spots. Since only those polypeptides showing position variation showed a positive correlation with molecular weight, this indicates the allelic nature of these polymorphisms, whereas spots showing presence/absence or quantitative variation did not particularly involve large polypeptides. These mutations were therefore probably located outside of the coding region of the polypeptide.
Hence, the results showed that both allelic and non-allelic variations were more frequent in polypeptides found in a single organ. However, the trend was more pronounced for spots showing quantitative variation. Therefore, reduced 'functional constraints' (Kimura, 1983) might explain the increased level of allelic variability of organ-specific polypeptides that are expressed in a single cellular environment, as suggested by Klose (1982). In the case of the quantitative variations, however, another factor must be involved. Following de Vienne et al (1988), we suggest here that the larger number of genetic elements involved in the regulation of the protein amounts further increases the difference with the 'housekeeping' proteins (organ-unspecific). Indeed, the extent of genetic variation observed could primarily reflect the number of possible targets for mutations: those proteins which are differentially regulated among organs are likely to possess more controls (ie, their regulation involves more genetic elements).

These results should be borne in mind by investigators studying the molecular basis of adaptative characters: although a large fraction of proteins do not show spatial or temporal regulation of their expression, these housekeeping proteins are not very variable, and therefore less likely to be of interest in these studies of complex characters. For instance, despite the large gametophytic/ sporophytic overlap in gene expression, only a limited fraction of variable proteins are common to both stages, reducing the efficiency of a haploid selection for the diploid stage.

\section{Linkage analysis}

We first used 56 megagametophytes of a single tree to build a map containing 90 protein loci in 12 linkage groups (table I, study \#4). These markers fitted the expected 1:1 Mendelian ratio. Fifty-eight spots arranged in 29 pairs corresponded to allelic products 
of structural genes varying in position. Twenty-two spots concerned presence/ absence variations. These polymorphisms could be determined by the presence of two alleles at a regulatory locus. Another possibility is that one of the alleles is indeed silent, ie, never encoding any product. Finally, the intensity of 39 spots could be classified into two discrete classes. This situation could be explained by the existence of major genes responsible for the determinism of polypeptide amounts. A total of $38 \%$ of the proteins were clustered at two loci. Each group of covariable spots could be explained by the action of a single regulatory locus having a pleiotropic effect on several different proteins (Gottlieb and de Vienne, 1988; Gerber et al, 1993), or post-translational modifications affecting allelic products of a single structural gene. A second linkage map was constructed using 18 maritime pine trees with an average of 12 megagametophytes per tree (table I, study \#5). Sixty-five loci organized into 17 linkage groups were identified. Recently, a RAPDbased map of an individual (accession 'H12') was complemented with 44 protein markers, 27 of which were assayed on megagametophytes of germinated seeds (table I, study \#6) and 17 on needles of the $\mathrm{F}_{2}$ selfed progeny of 'H12' (table I, study \#7). These protein loci were well distributed on the genome.

A summary of linkage information in the form of a single species map is a desirable goal for many general applications such as plant improvement and understanding genome evolution. In conifers, RAPD markers have been intensively used to construct single tree maps because the technique is rapid and reliable. However, a limitation of the RAPD for constructing a 'species' map is their questionable locus specificity when assessments are made on different individuals. In contrast, the same protein markers can be identified from the same or different organs of different trees within a species (table I, studies \#3 and \#5) and could be used as anchor points to join single tree maps constructed with RAPD markers, for example. Duplicated RFLP loci have been reported in crop plants (eg, Tanksley et al, 1988; Slocum et al, 1990; Song et al, 1991) and in trees (Devey et al, 1994). In addition, Lark et al (1993) showed that some linked RFLP markers in a cross of soybean did not correspond with any single linkage group in another cross, which could indicate that a given probe identifies different polymorphic fragments in the two crosses. RFLPs not only detect coding region polymorphism but also non-coding regions adjacent to coding DNA (Havey and Muehlbauer, 1989), and pseudogenes. Conversely, pseudogenes are not expressed. Therefore, compared to RFLPs, protein polymorphisms will not be affected by polymorphisms detected in pseudogenes. Gerber et al (1993) identified protein markers inherited in a Mendelian manner that were assumed to be homologous among 18 individuals of maritime pine. Position shift and presence/absence variants are simple to interpret on 2D gels (Bahrman and Damerval, 1989; Gerber et al, 1993), whereas proteins showing staining intensity variations may have a more complex genetic determinism involving several regulatory factors (Damerval et al, 1994). Thus, the two former variations could be used as anchor points to join single tree maps. Evidently, protein markers will not be heterozygous at the same loci for unrelated trees. However, the linkage relationship between two loci could be studied only in 'informative' genotypes that are heterozygous at these two loci, and human genetics mapping strategies (Gerber et al, 1993) and statistical methods for merging linkage maps (Stam, 1993) could be used for making connections among future linkage maps.

\section{CONCLUSION}

Assessing genetic diversity in tree species for breeding purposes or to manage genetic 
resources requires a large genome sampling which can be obtained by using the twodimensional electrophoresis of proteins. The value of this approach was demonstrated in several studies of maritime pine carried out in our laboratory and summarized here. By studying protein variation in the haploid tissue of the seeds, genetic markers were obtained which can be used for diversity and genome mapping studies.

Combining data on protein expression in different organs and protein polymorphism has been rarely performed. For the first time in a forest tree species, important results have been obtained on this topic.

Finally, the mapped protein markers can provide a scaffold of expressed sequences of the genome that should allow the study of relationships between structural genes and putative QTLs in future quantitative trait dissection analysis in that species.

\section{ACKNOWLEDGMENTS}

We thank P Costa and two anonymous reviewers for their helpful comments on the manuscript.

\section{REFERENCES}

Anderson NG, Tollaksen SL, Pascoe FH, Anderson NL (1985) Two-dimensional electrophoretic analysis of wheat seed proteins. Crop Sci 25, 667-674

Bahrman N, Damerval C (1989) Linkage relationships of loci controlling protein amounts in maritime pine (Pinus pinaster Ait). Heredity 63, 267-274

Bahrman N, Petit RJ (1995) Genetic polymorphism in maritime pine (Pinus pinaster Ait) assessed by twodimensional gel electrophoresis of needle, bud and pollen proteins. $J$ Mol Evol 41, 231-237

Bahrman N, Zivy M, Damerval C, Baradat P (1994) Organisation of the variability of abundant proteins in seven geographical origins of maritime pine (Pinus pinaster Ait). Theor App/ Genet 88, 407411

Baradat PH, Bernard-Dagan C, Fillon C, Marpeau A, Pauly G (1972) Les terpènes du pin maritime: aspects biologiques et génétiques. II. Hérédité de la teneur en monoterpènes. Arm Sci For 29, 307-334

Baradat Ph, Bernard-Dagan C, Marpeau A (1974) Les terpènes du pin maritime : aspects biologiques et génétiques. III. Hérédité de la teneur en myrcène. Ann Sci For 32, 29-54

Baradat P, Lambardi M, Michelozzi M (1989) Terpene composition in four Italian provenances of Aleppo pine (Pinus halepensis Mill). J Genet Breed $43,195-200$

Bergmann F, Gregorius HR (1979) Comparison of the genetic diversities of various populations of Norway spruce (Picea abies). In: Proceedings of the IUFRO Conference on Biochemical Genetics of Forest Trees (D Rudin, ed), Umea, Sweden, 1978, 99-107

Binelli G. Bucci G (1994) A genetic linkage map of Picea abies Karts, based on RAPD markers, as a tool in population genetics. Theor Appl Genet 88 , 283-288

Botstein D, White RL, Skolnick M, Davis RW (1980) Construction of a genetic linkage map in man using restriction fragment length polymorphisms. Am $J$ Hum Genet 32, 314-331

Bucci G, Menozzi P (1993) Segregation analysis of random amplified polymorphic DNA (RAPD) markers in Picea abies Karst. Mol Ecol 2, 227-232

Bucci G, Menozzi P (1995) Genetic variation of RAPD markers in a Picea abies Karst population. Hereditv 75, 188-197

Carlson JE, Tulsieram LK, Glaubity JC, Luk VWK, Kauffeld C, Rutledge R (1991) Segregation of random amplified DNA markers in $\mathrm{Fl}$ progeny of conifers. Theor Appl Cenet 83, 194-200

Conkle MT (1981) Isozymes variation and linkage in six conifer species. Proc Symp Isozymes of North Amcrican Forcst Trees and Forest Insects. USDA For Serv Gen Tech Rep PSW 48, 11-17

Damerval C, de Vienne D, Zivy M, Thiellement H (1986) Technical improvements in two-dimensional electrophoresis increase the level of genetic variation detected in wheat-seedling proteins. Elec. trophoresis 7, 52-54

Damerval C, Le Guilloux M, Blaisonneau J, de Vienne D (1987) Simplification of the Heukeshoven and Dernick's silver staining of proteins. Electrophoresis 8, 158-159

Damerval C, Maurice A, Josse JM, de Vienne D (1994) Quantitative trait loci underlying gene product variation: a novel perspective for analyzing regulation. of genome expression. Genetics 137, 289-301

Devey ME. Fiddler TA, Liu BH, Knapp SJ. Neale BD (1994) A RFLP linkage map for loblolly pine based on a three-generation outbred pedigree. Theor Appl Genet 88, 273-278

Domon JM, Meyer Y, Faye L. David A, David H (1994) Extracellular(glyco) proteins in embryogenic and non-embryogenic cell lines of Caribbean pine. Comparison between phenotypes of stage one somatic embryos. Plant Physiol Biochem 32, 137 147

Ekramoddoullah AKM, Taylor D, Hawkins BJ (1995) Characterization of a fall protein of sugar pine and detection of its homologue associated with frost 
hardiness of western white pine needles. Can J For Res $25,1137-1147$

Esteban I, Bergmann F, Gregorius HR, Huhtine O (1976) Composition and genetics of monoterpenes from cortical oleoresin of Norway spruce and their significance for clone identification. Silvae Genet $25,59-66$

Flinn BS, Roberts DR, Taylor EP (1991) Evaluation of somatic embryos of interior spruce. Characterization and developmental regulation of storage proteins. Physiol Plant 82, 624-632

Gerber S, Rodolphe F, Bahrman N, Baradat P (1993) Seed-protein variation in maritime pine (Pinus pinaster $\mathrm{Ait}$ ) revealed by two-dimensional electrophoresis: genetic determinism and construction of a linkage map. Theor Appl Genet 85, 521-528

Granier F, de Vienne D (1986) Silver staining of proteins: standardized procedure for two-dimensional gels bound to polyester sheets. Anal Biochem 155, 45-50

Giannini R, Vendramin G, Morgante M (1991) Allozyme variation in Italian population of Picea abies (L) Karst. Silvae Genet 40, 160-166

Gottlieb LD, de Vienne D (1988) Assessment of pleiotropic effects of a gene substitution in pea by two-dimensional polyacrylamide gel electrophoresis. Genetics 119, 705-710

Groome MC, Axler SR, Gifford DJ (1991) Hydrolysis of lipid and protein reserves in loblolly pine seeds in relation to protein electrophoretic patterns following imbibition. Physiol Plant 83, 99-106

Groover A, Devey M, Fiddler T, Lee J, Megraw R, Mitchel-Olds T, Sherman B, Vujcic S, Williams C, Neale D (1994) Indentification of quantitative trait loci influencing wood specific gravity in an outbred pedigree of loblolly pine. Genetics 138 , 1293-1300

Havey MJ, Muehlbauer FJ (1989) Linkages between restriction fragment length, isozyme and morphological markers in lentil. Theor Appl Genet 77, 395401

Irving RS, Adams RP (1973) Genetic and biosynthetic relationships of monoterpenes. Rec Adv Phytochem $6,187-214$

Kesseli RV, Paran I, Michelmore RW (1994) Analysis of a detailed genetic linkage map of Lactuca sativa (lettuce) constructed from RFLP and RAPD markers. Genetics 136, 1435-1446

Kimura M (1983) The Neutral Theory of Molecular Evolution. Cambridge University Press, Cambridge, UK

Klose J (1982) Genetic variability of soluble proteins studied by two-dimensional electrophoresis on different inbred mouse strains and on different mouse organs. J Mol Evol 18, 315-328

Kriebel HB (1985) DNA sequence components of Pinus strobus nuclear genome. Can J For Res 15 , $1-4$
Kubisiak TL, Nelson CD, Nance WL, Stine M (1995) RAPD linkage mapping in a lonleaf pine $x$ slash pine family. Theor Appl Genet 90, 11 19-1127

Lander ES, Green P (1987) Construction of multilocus genetic linkage maps in humans. Proc Natl Acad Sci USA 84, 2363-2367

Lark KG, Weiseman JM, Matthews BF, Palmer R, Chase K, Macalma T (1993) A genetic map of soybean (Glycine max $\mathrm{L}$ ) using an intraspecific cross of two cultivars: 'Minosy' and 'Noir 1'. Theor Appl Genet $86,901-906$

Marpeau A, Baradat P, Bernard-Dagan C (1975) Les terpènes du pin maritime : aspects biologiques et génétiques. IV. Hérédité de la teneur en deux sesquiterpènes : le longifolène et le caryophyllène. Ann Sci For 32, 185-203

Marpeau A, Baradat P, Bernard-Dagan C (1983) Les terpènes du pin maritime : aspects biologiques et génétiques. V. Hérédité de la teneur en limonène. Ann Sci For 40, 197-216

Miksche JP, Hotta Y (1973) DNA base composition and repetitious DNA in several conifers. Chromosoma 41, 29-36

Mosseler A, Egger KN, Hughes GA (1992) Low levels of genetic diversity in red pine confirmed by random amplified polymorphic DNA markers. Can I For Res 22, 1332 - 1337

Müller-Starck G (1987) Genetic differentiation among seed sample provenances of Pinus sylvestris L. Silvae Genet 36, 232-238

Müller-Starck G, Baradat P, Bergmann F (1992) Genetic variation within European tree species. Nen Forests 6, 23-47

Neale DB, Sederoff RR (1989) Paternal inheritance of chloroplast DNA and maternal inheritance of mitochondrial DNA in loblolly pine. Theor Appl Genet $77,212-216$

Neale DB, Wheeler NC, Allard RW (1986) Paternal inheritance of chloroplast DNA in Douglas-fir. Can J For Res 16, 1152-1154

Nei M (1987) Molecular Evolutionary Genetics. Columbia University Press, New York, NY, USA

Nelson CD, Nance WL, Doudrick RL (1993) A partial genetic linkage map of Slash pine (Pinus elliottii Englem var elliottii) based on random amplified polymorphic DNAs. Theor Appl Genet 87, 145151

Niebling CR, Johnson K, Gerhold HD (1987) Electrophoretic analysis of genetic linkage in Scots pine (Pinus sylvestris L). Biochem Genet 25, 803-814

O'Farrell PH (1975) High resolution two-dimensional electrophoresis of proteins. J Biol Chem 250, 4007402 ]

Ohri D, Khoshoo TN (1986) Genome size in gymnosperms. Pl Syst Evol 153, 1 19-131

Petit RJ, Bahrman N, Baradat P (1995) Comparison of genetic differentiation in maritime pine (Pinus 
pinaster Ait) estimated using isozyme, total protein and terpenic loci. Heredity 75, 382-389

Plomion C (1995) Cartographie et déterminisme génétique de la hauteur juvenile chez le pin maritime (Pinus pinaster Ait) en condition de croissance accélérée. Thèse de doctorat de l'Ensar, Rennes, France, $187 \mathrm{p}$

Plomion C, O'Malley DM, Durel C-D (1995a) Genomic mapping in maritime pine (Pinus pinaster). Comparison of two RAPD maps using selfed and open-pollinated seeds of the same individual. Theor Appl Genet 90, 1028-1034

Plomion C, Bahrman N, Durel CD, O'Malley DM (1995b) Genomic mapping in Pinus pinaster (maritime pine) using RAPD and protein markers. Heredity 74, 661-668

Rake AV, Mikshe JP, Hall RB, Hansen KM (1980) DNA reassociation kinetics of four conifers. Can J Genet Cyt 22, 69-79

Schiller G, Grunwald C (1987) Resin monoterpenes in rang-wide provenance trials of Pinus halepensis in Israel. Silvae Genet 36, 109-114

Schneider WL, Gifford DL ( 1994) Loblolly pine seed dormancy. I. The relationship between protein synthesis and the loss of dormancy. Physiol Plant 90 , 246-252

Sieffert A, Queiroz O (1989) Synergistic interaction of drought and $\mathrm{SO}_{2}$ pollution on the protein pattern of Picea abies needles. Plant Physiol Biochem 27, 269-274

Slocum MK, Figdore SS, Kennard WC, Suzuki YK, Osborn TC (1990) Linkage arrangement of restriction fragment length polymorphism loci in Brassica oleoraceae. Theor Appl Genet 80, 57-64

Song KM, Suzuki JY, Slocum MK, Williams PH, Osborn TC (1991) A linkage map of Brassica rapa (syn campestris) based on restriction fragment length polymorphism loci. Theor Appl Genet 82 , 296-304

Stam P (1993) Construction of integrated genetic linkage map by means of a new computer package: Join map. Plant J 3, 739-744

Strauss SH, Conkle MT (1986) Segregation, linkage and diversity of allozymes in knobcone pine. Theor Appl Genet 72, 483-493

Szmidt A (1982) Genetic variation in isolated populations of stone pine (Pinus cembra). Silva Fenn $16,196-200$

Tanksley SD, Bernatzky R, Lapitan NL, Prince JP (1988) Conservation of gene repertoire but not gene order in pepper and tomato. Proc Natl Acad Sci USA 85, 6419-6423

Tulsieram LK, Glaubitz JC, Kiss G, Carlson JE (1992) Single tree genetic linkage analysis in conifers using haploid DNA from megagametophytes. BiofTechnol 10, 686-690

Vienne D de, Leonardi A, Damerval C (1988) Genetic aspects of variation of protein amounts in maize and pea. Electrophoresis 9, 742-750

Wagner DB, Furnier GR, Saghai-Maroof MA Williams SM, Dancik BP, Allard RW (1987) Chloroplast DNA polymorphisms in lodgepole and jack pines and their hybrids. Proc Natl Acad Sci USA 84, 2097-2100

Wakamiya I, Newton RJ, Johnston JS, Price HJ (1993) Genome size and environmental factors in the genus Pinus. Am J Bot 80, 1235-1241

Williams JGK, Kubelik AR, Livak KJ, Rafalski JA (1990) DNA polymorphisms amplified by arbitrary primers are useful as genetic markers. Nucl Acids Res 18, 6531-6535

Yazdani R, Rudin R, Aldén T, Lindgren L, Harbom $B$, Ljung K (1982) Inheritance pattern of five monoterpenes in Scots pine. Hereditas 97, 261272 